\title{
Research on the Competitiveness of High-tech Service Industry in Dalian Fan Xiaonan ${ }^{1, a}$, Lv Jiaqi ${ }^{2, b}$
}

\author{
'Dalian Polytechnic University, Dalian,116034,China \\ ${ }^{2}$ Dalian Polytechnic University, Dalian,116034,China \\ acatfxn1981@sina.com, ${ }^{b 1175445650 @ q q . c o m}$
}

Keywords: high-tech service industry competitiveness; factor analysis; influencing factors

\begin{abstract}
From the 90s of last century, the service industry began to change from labor-intensive service-oriented to technology-intensive service-oriented. The high-tech service industry has the advantage of technological innovation, which makes great contribution to the economic growth. In recent years, the high-tech service industry of Dalian has grown steadily, but the competitiveness is not obvious. This paper constructs a high-tech service industry competitiveness evaluation index system, uses factor analysis method to estimate the comprehensive score of high-tech service industry competitiveness of 10 influential cities including Dalian in 2014, and at last offers some suggestions.
\end{abstract}

\section{Introduction}

In October 2015, the eighteenth Central Committee' s fifth plenary meeting on the " thirteenth five-year plan for national economy and social development ", the meeting proposed to accelerate the development of modern service industry to carry out the action. High-tech service industry is an important part of the modern service industry. In recent years, domestic and foreign scholars mainly study from the connotation ,characteristics of high-tech service industry and the classification ${ }^{[1-2]}$, measuring the development level of high-tech service industry ${ }^{[2-3]},{ }^{[4-5]}$ factors affecting the development of high-tech service industry, the relationship between high-tech service industry and manufacturing industry, exploration and research on what high-tech service industry devote to economic growth and other aspects. This paper analysed and evaluated the competitiveness of high-tech service industry in Dalian and put forward countermeasures to improve it in Dalian from city's perspective.

\section{The Development of High-tech Service Industry in Dalian}

Combined with the actual development of Dalian, the field of high-tech service industry in Dalian is defined as the following areas and industries in table 1.

Table 1 specific areas of Dalian high-tech services

\begin{tabular}{ll}
\hline \multicolumn{1}{c}{ fields } & \multicolumn{1}{c}{ Specific industries } \\
\hline Information transmission, software and IT services & $\begin{array}{l}\text { Telecommunications, radio and television and satellite } \\
\text { transmission services, Internet and related services, } \\
\text { software and IT services; }\end{array}$ \\
\hline Finance & $\begin{array}{l}\text { Monetary and financial services, insurance, capital } \\
\text { market services, other financial sectors }\end{array}$ \\
\hline Business services & $\begin{array}{l}\text { Legal services, consulting and other business services; } \\
\text { Scientific research, technical service industry }\end{array}$ \\
$\begin{array}{l}\text { Research and test development, professional and } \\
\text { technical services, technology promotion and application } \\
\text { services }\end{array}$ \\
\hline Water conservancy, environment and public facilities \\
management & $\begin{array}{l}\text { Water management, public facilities management, } \\
\text { ecological protection and environmental governance }\end{array}$ \\
\hline
\end{tabular}


The total output of high-tech service industry in 2005-2014 in Dalian steadily grew, reached 192 billion 570 million yuan in 2014 , and the total number of the statistical range of high-tech service companues in Dalian in five major areas is 1323 , accounting for $15.69 \%$ in the totol number of enterprises in Dalian, the average number of employees is 179191 people, patents per million people has reached 9.5, ranking first in Liaoning Province, the increase of high-tech service industry reached 109 billion 232 million 60 thousand yuan, accounting for $14.27 \%$ of GDP, see Table 2 .

Table 2 Specific information of the industry in 2014

\begin{tabular}{lccc}
\hline \multicolumn{1}{c}{ industry } & units & output & $\begin{array}{c}\text { average number of } \\
\text { employees }\end{array}$ \\
\hline $\begin{array}{l}\text { Information transmission, software and } \\
\text { IT services }\end{array}$ & 232 & 4986008 & 60156 \\
\hline Finance & 196 & 8420556 & 56520 \\
\hline Business services & 375 & 3259016 & 26479 \\
\hline $\begin{array}{l}\text { Scientific research and technical } \\
\text { services }\end{array}$ & 387 & 2219827 & 14722 \\
\hline Water conservancy, environment and & 133 & 371568 & \\
\hline public facilities management & & & \\
\hline
\end{tabular}

\section{High-tech Service Industry Competitiveness Index System}

The evaluation index system of high-tech service industry competitiveness is ${ }^{[3]}$ a multi-level index system, we referred to a variety of related literature and data, and according to the scientific principle, comprehensive principle, continuity principle, operational principle and importance principle, we established the evaluation system of high-tech service industry competitiveness, see Table 3 .

Table 3 high-tech service industry competitiveness index system

\begin{tabular}{cl}
\hline First level index & second level index \\
\hline basic condition & Per capita GDP(X1); \\
& Patent authorization number (X2); \\
& Government investment in public services (X3) \\
\hline development level & high-tech service industry added value $(\mathrm{X} 4) ;$ \\
& Number of employees in high-tech \\
& services $(X 5) ;$ \\
& high-tech service industrv's total output $(X 6)$ \\
\hline development potential & College graduate or above (X7); \\
& Fixed asset investment in high-tech \\
& services(X8) \\
\hline
\end{tabular}

\section{Empirical Analysis of the Competitiveness of High-tech SErvice Industry in Dalian}

3.1 Data Collection According to the development of Dalian high-tech service industry, we selected 9 cities whose high-tech service industry develops well and data are available and compared with Dalian. According to the evaluation index system of high-tech service industry competitiveness established above, obtained the data from the statistical yearbook and the statistics communique in 2014.

\subsection{Factor Analysis Process and Results}

(1) Standardize the Initial Data First of all, the statistical analysis software SPSS is used to deal with the original data, so as to avoid the problems of the evaluation index in the interpretation of the coefficients.

(2) Calculate the Correlation Coefficient Matrix The correlation coefficient between each index is large, indicating that there is a certain correlation between the indicators, which is suitable for factor analysis.

\section{(3)Factor Analysis}


1) Extraction of common factors

The common factor Scree plot (see Figure 2) and the total explanatory variables table (see Table 4) are generated by using the software SPSS. We can see that the cumulative contribution rate of the first 3 components is up to $90.259 \%$, which shows that the first 3 factors can fully reflect the information of the original data.

Table 4 total explanatory variables table

\begin{tabular}{|c|c|c|c|c|c|c|c|c|c|}
\hline \multirow{2}{*}{$\begin{array}{l}\text { Comp } \\
\text {-onent }\end{array}$} & \multicolumn{3}{|c|}{ Initial eigenvalues } & \multicolumn{3}{|c|}{$\begin{array}{l}\text { Extracting sums of the square } \\
\text { loading }\end{array}$} & \multicolumn{3}{|c|}{ Rotation sums of the square loading } \\
\hline & Total & $\begin{array}{l}\% \text { of } \\
\text { value }\end{array}$ & $\begin{array}{c}\text { Cumulative } \\
\%\end{array}$ & Total & $\begin{array}{l}\% \text { of } \\
\text { value }\end{array}$ & Cumulative\% & Total & $\begin{array}{l}\% \text { of } \\
\text { value }\end{array}$ & Cumulative $\%$ \\
\hline 1 & 4.826 & 60.321 & 60.321 & 4.826 & 60.321 & 60.321 & 4.711 & 58.893 & 58.893 \\
\hline 2 & 1.424 & 17.801 & 78.122 & 1.424 & 17.801 & 78.122 & 1.405 & 17.562 & 76.455 \\
\hline 3 & 0.971 & 12.137 & 90.259 & 0.971 & 12.137 & 90.259 & 1.104 & 13.804 & 90.259 \\
\hline 4 & 0.464 & 5.795 & 96.053 & & & & & & \\
\hline 5 & 0.264 & 3.301 & 99.355 & & & & & & \\
\hline 6 & 0.031 & 0.386 & 99.740 & & & & & & \\
\hline 7 & 0.017 & 0.214 & 99.955 & & & & & & \\
\hline 8 & 0.004 & 0.045 & 100.000 & & & & & & \\
\hline
\end{tabular}

2) Determine the main factors

It can be seen from table 5 that the cumulative three factors' contribution rate reached $90.259 \%$, more than $85 \%$. At the same time, the covariance matrix of factor scores shows there is no correlation between different factors. Therefore, the first 3 factors are selected as the main factors.

3) Empirical analysis

According to the corresponding contribution rate to calculate the total score, it's :

$$
\sum F=0.58893 \mathrm{~F} 1+0.17562 \mathrm{~F} 2+0.13804 \mathrm{~F} 3
$$

According to the above formula, we can get the ranking of the three factors and the competitiveness of high-tech service industry of 10 cities including Dalian in 2014, the results are shown in Table 5.

\begin{tabular}{|c|c|c|c|c|c|c|c|c|}
\hline & $\mathrm{F} 1$ & $\begin{array}{c}\mathrm{F} 1 \\
\text { ranking }\end{array}$ & $\mathrm{F} 2$ & $\begin{array}{c}\text { F2 } \\
\text { ranking }\end{array}$ & $\mathrm{F} 3$ & $\begin{array}{c}\text { F3 } \\
\text { ranking }\end{array}$ & $\begin{array}{c}\text { Comprehensive } \\
\text { score }\end{array}$ & $\begin{array}{c}\text { Comprehensi } \\
\text {-ve ranking }\end{array}$ \\
\hline Dalian & -0.7385 & 9 & 0.3565 & 5 & 2.3219 & 1 & -0.0518 & 6 \\
\hline Beijing & 2.5576 & 1 & -0.4242 & 6 & 0.1991 & 4 & 1.4592 & 1 \\
\hline Shenyang & -0.3692 & 6 & -0.8785 & 9 & -0.2097 & 6 & -0.4007 & 7 \\
\hline $\begin{array}{c}\text { Guangzho } \\
\mathrm{u} \\
\end{array}$ & 0.5237 & 2 & 0.4930 & 4 & -0.3635 & 7 & 0.3448 & 3 \\
\hline Suzhou & 0.0750 & 4 & 1.6078 & 1 & 0.7046 & 2 & 0.4238 & 2 \\
\hline Hangzhou & 0.1122 & 3 & -0.4912 & 7 & -0.1683 & 5 & -0.0434 & 4 \\
\hline Ningbo & -0.0575 & 5 & 0.5956 & 3 & -0.8523 & 9 & -0.0470 & 5 \\
\hline Zhouhai & -0.7483 & 10 & 1.1197 & 2 & -1.2914 & 10 & -0.4223 & 8 \\
\hline Hefei & -0.6347 & 7 & -1.6442 & 10 & 0.2856 & 3 & -0.6231 & 9 \\
\hline Fuzhou & -0.7201 & 8 & -0.7345 & 8 & -0.6254 & 8 & -0.6394 & 10 \\
\hline
\end{tabular}




\section{Suggestions on the Improvement of the Competitiveness of Dalian High-tech Service Industry}

\subsection{Expand Industry Scale}

5.1.1 Promote Technological Innovation Under the Guidance of Market Demand Dalian should cultivate a large number of small and medium technology enterprises, strengthen innovation oriented enterprises. What's more,investment in science and technology is the fundamental guarantee.The establishment of Dalian patent alliance is an important step, which is in order to encourage high-tech service in domestic and foreign enterprises to apply for patents ${ }^{[3]}$.

5.1.2 Establish a Diversified Investing and Financial System Dalian should take government funding as a guide, promote the social capital investment, increase the risk investment .It should carry out the corresponding support plan to promote the development of small-scale enterprises and industrial support fund.Futhermore, the government should guide the proper financing and equity of the enterprise, and promote the financial cooperation among small businesses.

5.1.3 Attract Related Businesses to Settle Down It can not only bring more employment to the population of Dalian, but also can bing the rapid increase of high-tech service talents.In order to attract more promising enterprises, Dalian should create a good environment for the development of enterprises and urban living environment.

\subsection{Enhance Supporting Conditions}

5.2.1 Speed Up the Economic Development of Dalian The city's economic strength is the basis for the development of all industries.As a port city, Dalian should make full use of this advantage, try to develop the international market while developing the consumer market.

5.2.2 Introduction and Training of Talents Dalian should strengthen the cultivation of talents and be committed to the introduction of advanced talents. On the one hand, Dalian should improve the quality and quantity of personnel training, strengthen the innovation and entrepreneurship education for college students and cultivate professional talents; What's more, it's necessary to provide incentives in personnel relations, account migration, children's education, housing, wages, allowances, professional titles evaluation, research funding and other aspects.

5.3 Improve the Government's Industrial Policy First of all, the government should adopt corresponding policies to encourage the development of high-tech service industry in Dalian, such as corporate tax relief, financial support.Secondly, create a better competitive environment for the whole industry to help it grow healthily in the competition. Moreover,the government should form a perfect evaluation index to effectively solve the problems in the development of the industry.

\section{Acknowledgement}

Liaoning Education Department project（Number: W2015053）、Liaoning Provincial Department of education research management think tank project (Number: ZK2015088) 、 Liaoning Social science project (Number: 20161sljdwtzdian-03) 、Institute of higher education in Liaoning in 13th Five-Year "planning" project (Number: GHYB160102) 、The research results of the Dalian Social Science Association project (2016dlskyb112)

\section{References}

[1]Miles I, Kastrinos N, Bilderbeek R, et al. Knowledge-intensive business services: users, carriers and sources of innovation [R]. Brussels: European Commission, 1995: 32-45.

[2]Wang Yangdong, Zhang Jun, Feng Li. Research on evaluation method of high-tech service industry project[J]. Scientific and technological progress and Countermeasures, 2009, 26(8): 116-118.

[3]Shen Jing, Meng Yue, Yang Baozhu. Evaluation on innovation capability of China's high-tech 
service industry[J]. Technical Economy, 2014, 33(1): 39-47.

[4]Yao Zhenghai, Zhang Haiyan The construction of evaluation index system for the development environment of high-tech service industry[J]. Finance \& Economics, 2013(12): 112-120.

[5]Tian Xiaoping. A study on the relationship between high-tech service industry and manufacturing industry from the perspective of organizational ecology[J]. Research on technology economy and management,2015(12): 108-112. 